\title{
CCL2 is Modulated by Cytokines and PPAR- $\gamma$ in Anaplastic Thyroid Cancer
}

\author{
Silvia Martina Ferrari ${ }^{1}$, Giusy Elia ${ }^{1}$, Simona Piaggi ${ }^{2}$, \\ Enke Baldini $^{3}$, Salvatore Ulisse ${ }^{3}$, Mario Miccoli ${ }^{1}$, \\ Gabriele Materazzi ${ }^{4}$, Alessandro Antonelli ${ }^{1}$, Poupak Fallahi ${ }^{1}$.
}

${ }^{1}$ Department of Clinical and Experimental Medicine, University of Pisa, Via Savi, 10, 56126, Pisa, Italy; ${ }^{2}$ Department of Translational Research and of New Technologies in Medicine and Surgery, University of Pisa, Via Roma, 55, 56126, Pisa, Italy; ${ }^{3}$ Department of Experimental Medicine , "Sapienza" University of Rome, Roma, Italy; ${ }^{4}$ Department of Surgical, Medical, Molecular Pathology and Critical Area, University of Pisa, Via Savi, 10, 56126, Pisa, Italy.

\section{Corresponding author:}

Alessandro Antonelli, MD

Director: Immuno-Endocrine Section of Internal Medicine

Professor of Medicine

Head, Laboratory of Primary Human Cells

Department of Clinical and Experimental Medicine

University of Pisa, School of Medicine,

Honorary Editor, "Drugs" (IF=4.883)

Via Savi, 10, I-56126, Pisa, Italy

Phone: +39-050-992318

Fax: +39-050-993472

e-mail: alessandro.antonelli@med.unipi.it

Short Title: CCL2 in anaplastic thyroid cancer

Keywords: chemokines, CCL2, anaplastic thyroid cancer, cytokines, PPAR- $\gamma$, PPAR- $\gamma$ agonists, thiazolidinediones

Word count: 6347 


\section{Abstract}

Background and Objective: Chemokine (C-C motif) ligand (CCL)2, the prototype Th2 chemokine, is secreted by tumor cells, and has growth promoting effects. Whether CCL2 protumorigenic activities will be validated, then CCL2 and its receptor CCR2 may be therapeutic targets in cancer. Methods: We tested in "primary human anaplastic thyroid carcinoma (ATC) cells" (ANA) versus "normal thyroid follicular cells" (TFC): a) CCL2 secretion basally, after IFN- $\gamma$ and/or TNF- $\alpha$ stimulation; b) PPAR $\gamma$ activation by thiazolidinediones (TZDs), rosiglitazone or pioglitazone, on CCL2 secretion, and on proliferation and apoptosis in ANA.

Results: ANA produced basally CCL2, at a higher level versus TFC. IFN- $\gamma$ or TNF- $\alpha$ dose-dependently induced the CCL2 release in $3 / 6$ or 5/6 ANA, respectively, but in all TFC. IFN- $\gamma+$ TNF- $\alpha$ induced a synergistic release of CCL2 in all TFC, but only in 1/6 ATC. TZDs exerted an inhibition of CCL2 release in 3/6 ANA, while had no effect in TFC. Pioglitazone inhibition of ANA proliferation was not associated with the effect on CCL2; NF- $\kappa \mathrm{B}$ and ERK1/2 were basally activated in ANA, increased by IFN- $\gamma+$ TNF$\alpha$, and pioglitazone inhibited IFN- $\gamma+$ TNF- $\alpha$ activation. CCL2 serum levels were higher in 6 ATC patients than in 5 controls ( $813 \pm 345$ versus $345 \pm 212$, pg/mL; respectively; $P<0.01$, ANOVA).

Conclusion: ANA produce CCL2 basally and after cytokines stimulation, with an extremely variable pattern of modulation, suggesting different types of deregulation in the chemokine modulation. Serum CCL2 is increased in ATC patients. Further studies will be necessary to evaluate if CCL2 might be used as a marker in the follow-up of ATC patients. 


\section{Introduction}

Chemokines and their receptors are expressed by tumor cells and by host cells, in primary tumors and in metastatic loci, and they may have different effects on tumorigenesis [1].

Little is known about chemokines in anaplastic thyroid carcinoma (ATC) [2].

ATC is an endocrine malignancy, rare and rapidly fatal [3-7]. At present, the most effective drug for treating ATC is the multimodal treatment protocol that include surgery, chemotherapy (doxorubicin and cisplatin), and hyperfractionated accelerated external beam radiotherapy [8] (10 months median patient survival) [8]. Thus, the identification of an effective systemi c treatment for ATC would represent a considerable advance in the management of this fatal thyroid cancer [9]. Promising future directions include peroxisome proliferator-activated receptor- $\gamma(\operatorname{PPAR} \gamma)$ agonists, aurora kinase inhibitors and tyrosine kinase inhibitors [10-12], gene therapy [13] and oncolytic virotherapy [14, 15].

In humans PPAR $\gamma$ is a type II nuclear receptor, encoded by the PPARg gene [16, 17] that, upon activation, binds to DNA in complex with the retinoid X nuclear receptor (RXR), increasing or decreasing the transcription of specific genes. PPAR $\alpha, \operatorname{PPAR} \delta$, and PPAR $\gamma$ are the known three PPARs subtypes. PPAR $\gamma$ regulates glucose metabolism and fatty acid storage, stimulates lipid uptake and adipogenesis by fat cells, and is a regulator of adipocyte differentiation [18]. PPAR $\gamma$ is involved in the pathogenesis of different diseases: obesity, diabetes, atherosclerosis, and cancer. Its agonists are implicated in the treatment of hyperlipidaemia and hyperglycemia [19]. PPAR $\gamma$ decreases the inflammatory response of many cardiovascular cells, mainly endothelial cells [20], reduces atherosclerosis, activating the PON1 gene, that increases the synthesis and release of paraoxonase 1 from the liver [21].

PPAR $\gamma$ are involved in autoimmune disorders [22] and in carcinogenesis [23], too.

In ATC, Hayashi et al. showed the expression of both PPAR $\gamma$ gene and protein in 5 human cell lines [24]; cell proliferation was reduced by $\operatorname{PPAR} \gamma$ agonists inducing apoptosis. Moreover, PPAR $\gamma$ agonists decreased the invasive potential of the 5 ATC cell lines [24].

Aiello et al. [25] studied the biologic effects of the PPAR $\gamma$ agonists ciglitazone (CGZ) and rosiglitazone (RGZ) in ATC cell lines, and demonstrated that RGZ increased the expression of thyroid-specific markers of differentiation. 
Marlow et al. [26] showed that, the high-affinity PPAR $\gamma$ agonist RS5444, reactivating suppressed RhoB, induced the cyclin-dependent kinase inhibitor p21 and inhibited ATC cells proliferation.

Antonelli et al. have shown that pioglitazone (PGZ) and RGZ can reduce cell growth and proliferation in human primary ATC cells, from different patients [27]. Moreover, in another in vitro study it was shown that the results of chemosensitivity tests with PPAR $\gamma$ agonists in primary ATC cells obtained directly from fine-needle aspiration are similar to those obtained from biopsies [28, 29].

A recent paper showed that TZDs are able to modulate chemokine secretion also in ATC. In fact, ATC cells produced CXCL10 basally and after stimulation by cytokines, with an extremely variable pattern of modulation by TNF- $\alpha$, IFN- $\gamma$ or TZDs, suggesting for different types of dysregulation of the intracellular pathways involved in the chemokine modulation in ATC with respect to differentiated thyroid cancer (DTC) and control thyroid follicular cells (TFC) [30].

More recently a phase I study [31] was conducted in 15 ATC patients, to evaluate the potential effectiveness of paclitaxel and efatutazone (EFA) at different doses $(0.15 \mathrm{mg}$ of EFA in 7 patients, $0.3 \mathrm{mg}$ in 6 patients, and $0.5 \mathrm{mg}$ in 2 patients). One subject, administered with $0.3 \mathrm{mg}$ of EFA, had a PR; 7 patients had SD. The median times to progression in patients treated with $0.15 \mathrm{mg}$ and $0.3 \mathrm{mg}$ of EFA, were 48 and 68 days, while the median survival were 98 versus 138 days, respectively. This study suggested that the combination between EFA and paclitaxel was safe and tolerated and had biologic activity [31].

Chemokine (C-C motif) ligand (CCL)2 (or monocyte chemoattractant protein-1) is the prototype $\mathrm{T}$ helper (Th)2 chemokine. CCL2 can be secreted by tumor cells, and it has growth promoting effects [32], shown in animal models and clinical epidemiological studies. In case that protumorigenic activities of CCL2 will be validated, then CCL2 and its receptor CCR2 may be therapeutic targets in cancer [32].

ATC is strongly infiltrated by immune cells, specifically macrophages [33], that seem to have a determinant role in ATC development and progression. Tumor-associated macrophages (TAMs) may differentiate from peripheral blood monocytes recruited in a CCL2-dependent manner [34]. Virus-infected cells activate an antiviral response in order to block viral replication, involving the production of type I and type III interferons (IFNs) and the modulation of cytokine and chemokine release. Viruses have developed different strategies to oppose cellular antiviral mechanisms, for 
example by modulating the activity of transcription factors involved in the production of chemokines and cytokines [35].

Recently, it has been shown that the oncolytic adenovirus d1922-947, evaluated for the treatment of ATC, reduces interleukin (IL)-8 and CCL2 secretion by the tumor cell lines 8505-c and BHT101-5 through the displacement of NF-אB p65 from IL-8 and CCL2 promoters. Moreover, the dl922-947induced reduction of the secretion of IL-8 and CCL2 correlated with impaired tumor angiogenesis and decreased macrophage density in vitro and in vivo [15].

In this study we aimed to: a) evaluate CCL2 in ATC cells compared to normal TFC; b) test the effect of IFN- $\gamma$ and/or tumor necrosis factor (TNF)- $\alpha$ influence on the secretion of the $\beta$-chemokine CCL2 in primary ATC cells, in comparison with TFC; c) test the effect of PPAR $\gamma$ activation on CCL2 secretion, and proliferation in these cell types; d) evaluate the pathways involved in the modulation of CCL2 by cytokines and PPAR $\gamma$.

\section{Materials and Methods}

\section{Patients source for thyroid tissue}

Thyroid tissues were collected from 8 ATC patients undergoing thyroidectomy, and normal thyroid tissues from 5 patients ( 2 during parathyroidectomy, and 3 during laryngeal intervention). The diagnosis was determined according to known laboratory, clinical and histological criteria [36, 37]. The absence of expression of thyroperoxidase (TPO), thyrotropin (TSH) receptor, sodium/iodide symporter (NIS), and thyroglobulin $(\mathrm{Tg})$ was shown by immunohistochemistry.

Microdissection and DNA extraction, detection of BRAF mutation by polymerase chain reaction single strand conformation polymorphism and direct DNA sequencing were performed as previously described [38]. Informed consent to the study was obtained from all study subjects, and was approved by the local ethical committee.

\section{ATC cell culture}

ATC cell cultures were established as previously described [29, 39, 40].

The absence of expression of TPO, TSH receptor, NIS and Tg, and a partial and focal positivity to cytokeratin were shown by immunocytochemistry. 


\section{Thyroid follicular cells}

Thyrocytes were prepared as previously described [36].

\section{CCL2 secretion assay}

Cells were seeded (3000 cells) in 96-well plates in growth medium, that was removed after $24 \mathrm{~h}$, and cells were then washed in phosphate buffered saline (PBS), and incubated in medium without serum and phenol red. Cells were treated with IFN- $\gamma(500,1000,5000,10000 \mathrm{IU} / \mathrm{mL}$; R\&D Systems, MN, USA) and $10 \mathrm{ng} / \mathrm{mL}$ TNF- $\alpha$ (R\&D Systems), alone or in combination, for $24 \mathrm{~h}$. The concentration of TNF- $\alpha$ was chosen according to the results obtained from preceding experiments to have the highest responses. The supernatant was then collected and kept frozen at $-20^{\circ} \mathrm{C}$ until CCL2 assay.

In order to test the modulation of IFN- $\gamma$-induced chemokine secretion exercised by PPAR $\gamma$ activators, cells were treated with IFN- $\gamma(1000 \mathrm{IU} / \mathrm{mL})$ and TNF- $\alpha(10 \mathrm{ng} / \mathrm{mL})$ in the presence or absence of increasing concentrations $\left(0,1,10,20 \mathrm{mmol} \mathrm{L}^{-1}\right)$ of the PPAR $\gamma$ agonists RGZ (Glaxo, UK), or PGZ (Alexis Biochemicals, Switzerland) for $24 \mathrm{~h}$, and CCL2 was dosed in the supernatants by enzyme-linked immunosorbent assay (ELISA). The results are the mean for each sample, and the experiments were conducted in triplicate for each cell preparation.

The PPAR $\gamma$ agonists concentrations were selected on the basis of their near therapy doses $\left(5-10 \mathrm{mmol} \mathrm{L}^{-1}\right.$ for RGZ and PGZ) according to their pharmacokinetics (Cmax and area under the time-concentration curve, AUC) $[27,28]$.

\section{Cell viability test}

After treatment with 10 or $20 \mathrm{mmol} \mathrm{L}^{-1} \mathrm{PGZ}$ for $24 \mathrm{~h}$, viable cells were evaluated by the viability and proliferation test “Cell Proliferation Reagent WST-1” (Roche, Mannheim, Germany) [27-29, 37].

The experiments were conducted in triplicate for each sample. The results are the mean for each sample.

\section{Proliferation assay: cell counting}

The proliferation was evaluated also using the cell number counting with a hemocytometer, after treatment with 10 or $20 \mathrm{mmol} \mathrm{L}^{-1} \mathrm{PGZ}$ for $24 \mathrm{~h}$ [27-29, 37].

\section{ELISA for CCL2}

CCL2 levels were assayed in culture supernatants, and in the serum of $6 / 8$ of ATC patients and 5 controls, by a quantitative sandwich immunoassay using a commercially available kit (R\&D Systems). The mean 
minimum detectable dose was $4.6 \mathrm{pg} / \mathrm{mL}$. The intra- and inter-assay coefficients of variation were $4.6 \%$ and $5.7 \%$.

\section{Apoptosis determination- Hoechst uptake}

Primary ATC cell cultures (ANA) were seeded at a concentration of 35000 cells $/ \mathrm{mL}$ in a 96 -wells plate in a final volume of $100 \mathrm{~mL} /$ well, and treated with PGZ (10 or $\left.20 \mathrm{mmol} \mathrm{L}^{-1}\right)$ for $48 \mathrm{~h}$, in a humidified atmosphere $\left(37^{\circ} \mathrm{C}, 5 \% \mathrm{CO}_{2}\right)$, then stained with Hoechst 33342 [41-43].

It was calculated the apoptosis index (ratio between apoptotic and total cells x100), and the results were evaluated by analysis of variance (ANOVA) with Newman-Keuls multiple comparisons test.

\section{Apoptosis determination- Annexin V binding assay}

Cells were seeded in Lab-tekII Chamber Slide System (Nalge Nunc International, Naperville, IL, USA), treated with 10 or $20 \mathrm{mmol} \mathrm{L}^{-1} \mathrm{PGZ}$ for $48 \mathrm{~h}$, and processed as previously described [41-43].

\section{Nuclear extracts preparation}

ANA and TFC cells were seeded at a concentration of 200000 cells $/ \mathrm{mL}$ in cell culture dishes in $10 \mathrm{~mL}$ and treated with IFN- $\gamma(1000 \mathrm{IU} / \mathrm{mL})$ and TNF- $\alpha(10 \mathrm{ng} / \mathrm{mL})$ in the presence or absence of 10 or $20 \mathrm{mmol}$ $\mathrm{L}^{-1} \mathrm{PGZ}$ for $1 \mathrm{~h}$.

Nuclear extracts (nucleosol) were obtained as previously described [41].

\section{Electrophoretic mobility shift assay (EMSA)}

DNA binding reactions and electrophoresis were performed as previously described [41].

\section{Immunoblotting}

ANA cells were seeded at a concentration of 200000 cells $/ \mathrm{mL}$ in cell culture dishes in $10 \mathrm{~mL}$ and treated with IFN- $\gamma(1000 \mathrm{IU} / \mathrm{mL})$ and TNF- $\alpha(10 \mathrm{ng} / \mathrm{mL})$ in the presence or absence of 10 or $20 \mathrm{mmol} \mathrm{L}^{-1} \mathrm{PGZ}$ for $24 \mathrm{~h}$.

At the end of the treatments, cells were processed as previously described $[41,44]$.

\section{Data analysis}

Values are given as mean \pm standard deviation (SD) for normally distributed variables (in text), or mean \pm standard error of mean (SEM) (in figures), otherwise as median and [interquartile range]. Mean group values were compared by using one-way ANOVA for normally distributed variables, otherwise by the Mann-Whitney $U$ or Kruskal-Wallis test. Proportions were compared by the $\chi^{2}$ test. Post-hoc comparisons on normally distributed variables were carried out using the Bonferroni-Dunn test. 


\section{Results}

\section{In vitro studies}

In ATC cells, CCL2 was detectable basally in supernatants in all samples, higher levels were observed in preparations B, C, D, F, G and H, whilst a slight basal secretion was shown in A and E (Figure 1). The basal level of CCL2 in ATC supernatants ranged from 104 to $16207 \mathrm{pg} / \mathrm{mL}$, with a mean level of $6134 \pm$ $4973 \mathrm{pg} / \mathrm{mL}(P<0.05$, versus controls), showing a median increase with respect to the CCL2 level in TFC (Figure 2).

CCL2 release was induced dose-dependently by IFN- $\gamma$, only in preparations A, E, F, and H while had no effect in the other preparations (ANOVA, $P<0.05$, versus basal).

TNF- $\alpha$ alone in ATC cells dose-dependently induced the CCL2 release in all the preparations with the exception of preparation $\mathrm{A}$; the stronger effect was observed in $\mathrm{B}, \mathrm{C}$ and $\mathrm{G}$ (ANOVA, $P<0.05$, versus basal).

The combination of TNF- $\alpha$ and IFN- $\gamma$ had a significant synergistic effect on the CCL2 secretion (Figure 1) in preparation $\mathrm{A}$, and showed no effect in the others (ANOVA, $P<0.05$, versus IFN- $\gamma$ ).

Treating ATC cells with RGZ, in the presence of IFN- $\gamma$ and TNF- $\alpha$, CCL2 release was inhibited dosedependently (Figure 1) in preparations A, F and H (ANOVA, $P<0.05$, versus IFN- $\gamma+$ TNF- $\alpha$ ), while no significant effects were present in the others.

Similarly, the treatment of ATC cells with PGZ, in the presence of IFN- $\gamma$ and TNF- $\alpha$, dose-dependently inhibited CCL2 release (Figure 1) in preparations A, B, F and H (ANOVA, $P<0.05$, versus IFN$\gamma+$ TNF- $\alpha$ ), while no significant effects were present in the others.

CCL2 $(251 \pm 241 \mathrm{pg} / \mathrm{mL})$ was detectable in the supernatants collected from primary thyrocyte cultures. IFN- $\gamma$ dose-dependently induced the CCL2 release (CCL2: $255 \pm 236,521 \pm 283,967 \pm 489,1187 \pm 563$, $1389 \pm 652 \mathrm{pg} / \mathrm{mL}$; respectively, with IFN- $\gamma 0,500,1000,5000,10000 \mathrm{IU} / \mathrm{mL}$; ANOVA, $P<0.001)$ TNF- $\alpha$ dose-dependently induced the CCL2 release (CCL2: $247 \pm 243,438 \pm 289,694 \pm 354,859 \pm 496$ $\mathrm{pg} / \mathrm{mL}$; respectively, with TNF- $\alpha 0,1,5,10 \mathrm{ng} / \mathrm{mL}$; ANOVA, $P<0.001)$. The combination of IFN- $\gamma$ and TNF- $\alpha$ had a significant synergistic effect on the CCL2 secretion (ANOVA, $P<0.0001$ ) (Figure 2). The treatment of TFC with RGZ or PGZ, added at the time of IFN- $\gamma$ and TNF- $\alpha$ stimulation, had no significant effect on the CCL2 release (Figure 2). 
For comparison, we have reported mean CCL2 values in TFC (5 preparations) or in ANA (8 preparations) in Table 1.

Table 1. Mean CCL2 values in supernatant of thyroid follicular cells (TFC; 5 preparations), or in anaplastic thyroid cancer cells (ANA; 8 preparations).

\begin{tabular}{|lcccc|}
\hline & TFC & $P$ & ANA & $P$ \\
Basal & CCL2 $(\mathrm{pg} / \mathrm{mL})$ & & CCL2 $(\mathrm{pg} / \mathrm{mL})$ & \\
IFN- $\gamma$ 1000 IU/mL & $251 \pm 241$ & & $6134 \pm 4973$ & \\
TNF- $\alpha 10 \mathrm{ng} / \mathrm{mL}$ & $967 \pm 489$ & $<0.05^{*}$ & $7336 \pm 5312$ & $\mathrm{~ns}^{*}$ \\
INF- $\gamma+$ TNF- $\alpha$ & $859 \pm 496$ & $<0.05^{*}$ & $12956 \pm 7148$ & $<0.05^{*}$ \\
INF- $\gamma+$ TNF- $\alpha+$ Rosi & $2975 \pm 738$ & $<0.05^{\wedge}$ & $13044 \pm 8061$ & $\mathrm{~ns}^{\wedge}$ \\
INF- $\gamma+$ TNF- $\alpha+$ Pio & $3086 \pm 127$ & $\mathrm{~ns}^{\circ}$ & $11986 \pm 6893$ & $\mathrm{~ns}^{\circ}$ \\
& $2957 \pm 263$ & $\mathrm{~ns}^{\circ}$ & $11547 \pm 7124$ & $\mathrm{~ns}^{\circ}$ \\
\hline
\end{tabular}

$*=$ versus basal; ${ }^{\wedge}=$ versus $\mathrm{INF}-\gamma$ or TNF- $\alpha{ }^{\circ}=$ versus $\mathrm{INF}-\gamma+\mathrm{TNF}-\alpha$

The antiproliferative effect of PGZ was evidenced after a minimum of $24 \mathrm{~h}$ of incubation and increased with longer incubations, while no antiproliferative effects were reported with shorter treatment times (10 and $18 \mathrm{~h}$ ). The concentrations of thiazolidinedione (TZD; PGZ) required to obtain the IE $50(50 \%$ inhibition of growth) were calculated after 2 days (48 $\mathrm{h}$ of incubation). A reduction of proliferation compared to the control was demonstrated by WST-1 assay in ANA cells (after $48 \mathrm{~h}$ of incubation with 
PGZ) both at $1 \mathrm{~h}$ (Figure 3A) (from the start of tetrazolium reaction) [of $8 \%$ and 17\% with PGZ $10(P=$ ns) or $\left.20(P<0.01) \mathrm{mmol} \mathrm{L}^{-1}\right]$, and at $2 \mathrm{~h}$ (Figure 3B) [of $10 \%$ and $24 \%$ with PGZ $10(P<0.05)$ or 20 $\left.(P<0.0001) \mathrm{mmol} \mathrm{L}^{-1}\right](P$ by ANOVA $)$.

The cell counting confirmed the above mentioned results (data not shown).

The PGZ concentration necessary for IE 50 in ANA was $38 \mathrm{mmol} \mathrm{L}^{-1}$.

Apoptosis index was obtained in ATC cells using the Hoechst method. The fluorescent Hoechst dye stained both control and cells treated with PGZ (10 and $20 \mathrm{mmol} \mathrm{L}^{-1}$ for $48 \mathrm{~h}$ ). The percentage of apoptotic cells increased dose-dependently: $6 \%$ of the cells were apoptotic at the PGZ lower dose reaching more than 14\% with PGZ $20 \mathrm{mmol} \mathrm{L}^{-1}$ (ANOVA, $P<0.001$ ) (Figure 3C). The induced cell apoptosis was verified by Annexin V.

In order to clarify the PPAR $\gamma$ agonists-inhibition on CCL2 secretion, the EMSA assay was conducted to evaluate the effect of TZD on nuclear factor-kB (NF-kB) activation in the ATC cells (Figure 4A). NF-kB was constitutively activated in ATC cells (lane 3) and its DNA binding activity was increased by the treatment with IFN- $\gamma$ and TNF- $\alpha$ (lane 4 ). The NF-kB activation by IFN- $\gamma$ and TNF- $\alpha$ was significantly reduced by PGZ $\left(20 \mathrm{mmol} \mathrm{L}^{-1}\right)$ alone (lane 2) or in combination with IFN- $\gamma+\mathrm{TNF}-\alpha$ (lane 1 ) and also the treatment with $10 \mathrm{mmol} \mathrm{L}^{-1} \mathrm{PGZ}$ inhibited the nuclear translocation of NF-kB (data not shown). NF-kB was not constitutively activated in TFC cells, while it was induced by IFN- $\gamma+\mathrm{TNF}-\alpha$, and inhibited by PGZ (data not shown).

As regards mitogen-activated protein kinase (MAPK) extracellular-signal-regulated kinase 1/2 (ERK1/2), we demonstrated that ERK1/2 are activated at the basal level in ATC cells, and IFN- $\gamma+\mathrm{TNF}-\alpha$ increased its activation. PGZ $\left(20 \mathrm{mmol} \mathrm{L}^{-1}\right)$ inhibited the cytokines-induced ERK1/2 phosphorylation (Figure 4B). Three ATC presented the ${ }^{\mathrm{V} 600 \mathrm{E}} B R A F$ mutation. IFN- $\gamma$ and/or TNF- $\alpha$ stimulated chemokines secretion, RGZ and/or PGZ modulated it, and PGZ inhibited cell proliferation similarly both in ATC from tumors with ${ }^{\mathrm{V} 600 \mathrm{E}} B R A F$ mutation, and from tumors without $B R A F$ mutations (data not shown).

The proliferation of TFC cells was decreased slightly but not significantly by PGZ, while it had no effect on total protein content (data not shown). 


\section{In vivo studies}

CCL2 levels were measured in the serum of 6 ATC patients and 5 controls $(813 \pm 345$ versus $345 \pm 212$, $\mathrm{pg} / \mathrm{mL}$; respectively), showing significantly increased levels in ATC patients $(P<0.01$, by ANOVA). No relationship among CCL2 serum levels and the clinical presentations of the ATC patients was observed.

\section{Discussion}

Our results show that ANA produced basally CCL2, at a higher level compared to TFC. Furthermore, circulating CCL2 is increased in ATC patients. CCL2 chemokine is secreted by ATC cells, after the treatment with cytokines, with an extremely variable pattern of modulation (no effect, or inhibition, or stimulation) by TNF- $\alpha$, IFN- $\gamma$ or TZDs, and a variable strength of the induced effect. CCL 2 was secreted basally by TFC, and responded to IFN- $\gamma$ or TNF- $\alpha$, alone or in combination, in agreement with the results obtained by previous studies [45-47]. However, the basal level of CCL2 in ATC supernatants was higher compared to the CCL2 level in TFC. If CCL2 may be a marker of aggressiveness remains to be established.

IFN- $\gamma$ dose-dependently induced the CCL2 release only in 4/8 ATC preparations, while all TFC responded to IFN- $\gamma$. So far, it appears that progressive dedifferentiation of thyroid cells seems to increase the levels of basal CCL2 secretion while reducing its sensitivity to cytokines stimuli; this apparent discrepancy remains to be clarified.

TNF- $\alpha$ induced the CCL2 release in 7/8 ATC preparations, while the response was present in all TFC (in full agreement with the results obtained by other studies in TFC) [45-48].

IFN- $\gamma /$ TNF- $\alpha$ synergism on CCL2 secretion has been shown in TFC in our study, in agreement with the results of other papers [45-47]. However, IFN- $\gamma+\mathrm{TNF}-\alpha$ had a significant synergistic effect on the CCL2 secretion only in 1/8 ATC preparation, and showed no significant effect in the others.

Several intracellular signaling pathways have been identified that mediate the cytokines-induced CCL2 expression. Among them, NF-kB is a well-known transcription factor that mediates induction of CCL2 release in various cell types, by: a) IFN- $\gamma[49,50]$; b) TNF- $\alpha[51,52]$; c) or the combination of IFN$\gamma+\mathrm{TNF}-\alpha[46,47]$. 
In this study we demonstrate an increased NF-kB activation in ATC cells, after IFN- $\gamma$, or TNF- $\alpha$, or IFN$\gamma+$ TNF- $\alpha$ stimulation, and this apparently agrees with what observed in the above mentioned studies. However, probably other pathways are involved, too, as the NF-kB activation was present also in ATC preparations in which the IFN- $\gamma$, or TNF- $\alpha$, or IFN- $\gamma+\mathrm{TNF}-\alpha$ stimulatory effect on CCL2 was not observed.

The involvement of ERK activation in CCL2 induction by TNF- $\alpha$ has been shown also by other studies $[53,54]$. We demonstrate that ERK $1 / 2$ are basally activated in ATC cells, and IFN- $\gamma+$ TNF- $\alpha$ stimulated phosphorylation and activation of ERK1/2. However, also in this case, a discrepancy between ERK activation and CCL2 secretion is observed, since the ERK activation was present also in ATC preparations in which the IFN- $\gamma+\mathrm{TNF}-\alpha$ stimulatory effect was not observed, reinforcing the hypothesis that probably other pathways are involved in the induction of CCL2 secretion in ATC.

PGZ exerted an inhibition of CCL2 release in preparations B, F and H, and a weak inhibitory effect in preparation A, while TZD had no effect in the other ATC, and in TFC. PPAR $\gamma$ activators have been shown to suppress CCL2 expression, via different pathways (MAPK phosphatase-1, Toll-like receptor) even in other cell types $[55,56]$.

As regards the mechanism of action involved in chemokine secretion, PPAR $\gamma$ agonists may act differently: 1) inhibiting NF-kB [57]; 2) increasing the phosphorylation and activation of ERK1/2 [58].

NF-kB was activated in ATC cells at the basal level and TZDs inhibited its activation, as reported by Marx et al. [57]. Considering the MAPKinase ERK1/2, we have shown that PPAR $\gamma$ agonists were able to inhibit the cytokines-induced ERK1/2 phosphorylation [58]. Our data support TZDs effect on ATC proliferation, but are not in agreement with TZDs effects on CCL2 secretion, leading to hypothesize that other pathways take part in the chemokine modulation in ATC.

Activation of PPAR $\gamma$ isoforms elicits both anti-neoplastic [59] and anti-inflammatory effects [36] in several types of mammalian cells. PPAR $\gamma$ are also expressed in human anaplastic cancer cell lines [24], and inhibited cell proliferation by inducing apoptosis [24]. Moreover, we have recently shown the antiproliferative effect of PPAR $\gamma$ agonists TZD in primary cultured human anaplastic and papillary dedifferentiated thyroid cancers cells [27, 28, 37].

Our study agrees that PPAR $\gamma$ agonists do not have an inhibitory effect in TFC, but report a significant antiproliferative effect in primary ATC cells. Of note, the modulation of IFN- $\gamma$-stimulated CCL2 
secretion and the antiproliferative effect of PPAR $\gamma$ activators in ATC are not related. The discrepancy between TZDs effects on CCL2 secretion and the inhibitory role on ATC proliferation is presumably linked to the different involved pathways, as TZDs mediate growth inhibition inducing apoptosis, as previoulsy suggested by other studies [60].

CCL2 was measured in the serum of 6 ATC patients and 5 controls, showing significantly increased levels in ATC patients. No relationship among CCL2 serum levels and the clinical presentations of the ATC patients was observed, possibly because of the limited number of tested samples. CCL2 is secreted by tumor cells, and it has growth promoting effects [32], reported in animal models and clinical epidemiological studies. CCL2 could promote tumor progression in two ways. CCL2 might be secreted by tumor cells, or tumor cells could stimulate its secretion by close stromal or endothelial cells [32]. CCL2 might exert its effects recruiting mononuclear cells, that could secrete growth or survival factors that would enhance tumor progression, or they could provide angiogenic factors as VEGF that could stimulate vessel formation and lead to tumor growth. On the other hand, CCL2 could act in a paracrine or autocrine manner to promote tumor cell growth or survival. Whether protumorigenic activities of CCL2 will be validated, then CCL2 and its receptor CCR2 may be considered as therapeutic targets in cancer [32]. Further studies in larger numbers of ATC patients will be necessary to evaluate if CCL2 might be used as a marker in the follow-up of ATC patients.

On the whole, the present results first show that ANA produced basally CCL2, at a higher level compared to TFC, and that circulating CCL2 is increased in ATC patients. ATC cells produce the CCL2 chemokine, basally and stimulated by cytokines, even if with an extremely variable pattern of modulation (no effect, or inhibition, or stimulation) by IFN- $\gamma$, TNF- $\alpha$ or TZDs, as the strength of the induced response. Furthermore, a discrepancy between the variable TZDs effect on CCL2 secretion and the inhibitory role on ATC proliferation has been evidenced. These different modulatory effects in various ATC preparations suggest different types of deregulation in the intracellular pathways involved in the chemokine modulation, as already described about the secretion of the CXCL10 chemokine in ATC cells in primary cultures [30]. However, this knowledge may help in discovering new targets for the treatments of ATC. 


\section{Declaration of interest}

The authors declare that there is no conflict of interest that could be perceived as prejudicing the impartiality of the research reported.

\section{Funding}

This research did not receive any specific grant from any funding agency in the public, commercial or not-for-profit sector.

\section{Acknowledgements}

SMF, AA and PF gave substantial contribution to the conception and design of the work; GE, SP, EB, SU, MM and GM in the acquisition, analysis, and interpretation of data. SMF and PF wrote the paper, and AA, SU, GM revised it critically for important intellectual content. All the authors gave the final approval of the version to be published. 


\section{References}

[1] Raman, D.; Baugher, P.J.; Thu, Y.M.; Richmond, A. Role of chemokines in tumor growth. Cancer Lett., 2007, 256, 137-165.

[2] De Falco, V.; Guarino, V.; Avilla, E.; Castellone, M.D.; Salerno, P.; Salvatore, G.; Faviana, P.; Basolo, F.; Santoro, M.; Melillo, R.M. Biological role and potential therapeutic targeting of the chemokine receptor CXCR4 in undifferentiated thyroid cancer. Cancer Res., 2007, 67, 11821-11829.

[3] O’ Neill, J.P.; O'Neill, B.; Condron, C.; Walsh, M.; Bouchier-Hayes, D. Anaplastic (undifferentiated) thyroid cancer: improved insight and therapeutic strategy into a highly aggressive disease. J. Laryngol. Otol., 2005, 119, 585-591.

[4] Are, C.; Shaha, A.R. Anaplastic thyroid carcinoma: biology, pathogenesis, prognostic factors, and treatment approaches. Ann. Surg. Oncol., 2006, 13, 453-464.

[5] Ain, K.B. Anaplastic thyroid carcinoma: a therapeutic challenge. Semin. Surg. Oncol., 1999, 16, 64-69.

[6] Neff, R.L.; Farrar, W.B.; Kloos, R.T.; Burman, K.D. Anaplastic thyroid cancer. Endocrinol. Metab. Clin. North. Am., 2008, 37, 525-538.

[7] Antonelli, A.; Fallahi, P.; Ulisse, S.; Ferrari, S.M.; Minuto, M.; Saraceno, G.; Santini, F.; Mazzi, V.; D'Armiento, M.; Miccoli, P. New targeted therapies for anaplastic thyroid cancer. Anticancer Agents Med. Chem., 2012, 12, 87-93.

[8] De Crevoisier, R.; Baudin, E.; Bachelot, A.; Leboulleux, S.; Travagli, J.P.; Caillou, B.; Schlumberger, M. Combined treatment of anaplastic thyroid carcinoma with surgery, chemotherapy, and hyperfractionated accelerated external radiotherapy. Int. J. Radiat. Oncol. Biol. Phys., 2004, 60, 1137-1143.

[9] Wartofsky, L. Highlights of the American Thyroid Association Guidelines for patients with thyroid nodules or differentiated thyroid carcinoma: the 2009 revision. Thyroid, 2009, 19(11), 1139-1143.

[10] Ferrari, S.M.; La Motta, C.; Sartini, S.; Baldini, E.; Materazzi, G.; Politti, U.; Ruffilli, I.; Ulisse, S.; Miccoli, P.; Antonelli, A.; Fallahi, P. Pyrazolopyrimidine Derivatives as 
Antineoplastic Agents: with a Special Focus on Thyroid Cancer. Mini Rev. Med. Chem., 2016, 16, 86-93.

[11] Ferrari, S.M.; Fallahi, P.; Politti, U.; Materazzi, G.; Baldini, E.; Ulisse, S.; Miccoli, P.; Antonelli, A. Molecular Targeted Therapies of Aggressive Thyroid Cancer. Front. Endocrinol. (Lausanne), 2015, 6, 176.

[12]Ferrari, S.M.; Politti, U.; Spisni, R.; Materazzi, G.; Baldini, E.; Ulisse, S.; Miccoli, P.; Antonelli, A.; Fallahi, P. Sorafenib in the treatment of thyroid cancer. Expert. Rev. Anticancer Ther., 2015, 15, 863-874.

[13] Gholami, S.; Haddad, D.; Chen, C.H.; Chen, N.G.; Zhang, Q.; Zanzonico, P.B.; Szalay, A.A.; Fong Y. Novel therapy for anaplastic thyroid carcinoma cells using an oncolytic vaccinia virus carrying the human sodium iodide symporter. Surgery, 2011, $150,1040-1047$.

[14] Hallden, G.; Portella, G. Oncolytic virotherapy with modified adenoviruses and novel therapeutic targets. Expert Opin Ther Targets, 2012, 16, 945-958.

[15] Passaro, C.; Borriello, F.; Vastolo, V.; Di Somma, S.; Scamardella, E.; Gigantino, V.; Franco, R.; Marone, G.; Portella, G. The oncolytic virus d1922-947 reduces IL8/CXCL8 and MCP-1/CCL2 expression and impairs angiogenesis and macrophage infiltration in anaplastic thyroid carcinoma. Oncotarget, 2016, 7(2), 1500-1515.

[16] Chandra, V.; Huang, P.; Hamuro, Y.; Raghuram, S.; Wang, Y.; Burris, T.P.; Rastinejad, F. Structure of the intact PPAR-gamma-RXR- nuclear receptor complex on DNA. Nature, 2008, 456(7220), 350-356.

[17] Ferrari, S.M.; Materazzi, G.; Baldini, E.; Ulisse, S.; Miccoli, P.; Antonelli, A.; Fallahi, P. Antineoplastic Effects of PPAR $\gamma$ Agonists, with a Special Focus on Thyroid Cancer. Curr. Med. Chem., 2016, 23, 636-649.

[18] Jones, J.R.; Barrick, C.; Kim, K.A.; Lindner, J.; Blondeau, B.; Fujimoto, Y.; Shiota, M.; Kesterson, R.A.; Kahn, B.B.; Magnuson, M.A. Deletion of PPARgamma in adipose tissues of mice protects against high fat diet-induced obesity and insulin resistance. Proc. Natl. Acad. Sci.USA, 2005, 102, 6207-6212. 
[19]Li, Y.; Qi, Y.; Huang, T.H.; Yamahara, J.; Roufogalis, B.D. Pomegranate flower: a unique traditional antidiabetic medicine with dual PPAR-alpha/-gamma activator properties. Diabetes. Obes. Metab., 2008, 10, 10-17.

[20] Hamblin, M.; Chang, L.; Fan, Y.; Zhang, J.; Chen, Y.E. PPARs and the cardiovascular system. Antioxid. Redox Signal., 2009, 11, 1415-1452.

[21] Khateeb, J.; Gantman, A.; Kreitenberg, A.J.; Aviram, M.; Fuhrman, B. Paraoxonase 1 (PON1) expression in hepatocytes is upregulated by pomegranate polyphenols: a role for PPAR-gamma pathway. Atherosclerosis, 2010, 208(1), 119-125.

[22] Ferrari, S.M.; Fallahi, P.; Vita, R.; Antonelli, A.; Benvenga, S. Peroxisome ProliferatorActivated Receptor- $\gamma$ in Thyroid Autoimmunity. PPAR Res., 2015, 2015, 232818.

[23] Wei, S.; Yang, J.; Lee, S.L.; Kulp, S.K.; Chen, C.S. PPARgamma-independent antitumor effects of thiazolidinediones. Cancer Lett., 2009, 276, 119-124.

[24] Hayashi, N.; Nakamori, S.; Hiraoka, N.; Tsujie, M.; Xundi, X.; Takano, T.; Amino, N.; Sakon, M.; Monden, M. Antitumor effects of peroxisome proliferator activate receptor gamma ligands on anaplastic thyroid carcinoma. Int. J. Oncol., 2004, 24, 89-95.

[25] Aiello, A.; Pandini, G.; Frasca, F.; Conte, E.; Murabito, A.; Sacco, A.; Genua, M.; Vigneri, R.; Belfiore, A. Peroxisomal proliferator-activated receptor-gamma agonists induce partial reversion of epithelial-mesenchymal transition in anaplastic thyroid cancer cells.

Endocrinology, 2006, 147(9), 4463-4475.

[26] Marlow, L.A.; Reynolds, L.A.; Cleland, A.S.; Cooper, S.J.; Gumz, M.L.; Kurakata, S.; Fujiwara, K.; Zhang, Y.; Sebo, T.; Grant, C.; McIver, B.; Wadsworth, J.T.; Radisky, D.C.; Smallridge, R.C.; Copland, J.A. Reactivation of suppressed RhoB is a critical step for the inhibition of anaplastic thyroid cancer growth. Cancer Res., 2009, 69, 1536-1544.

[27] Antonelli, A.; Ferrari, S.M.; Fallahi, P.; Berti, P.; Materazzi, G.; Minuto, M.; Giannini, R.; Marchetti, I.; Barani, L.; Basolo, F.; Ferrannini, E.; Miccoli, P. Thiazolidinediones and antiblastics in primary human anaplastic thyroid cancer cells. Clin. Endocrinol. (Oxf)., 2009, 70, 946-953.

[28] Antonelli, A.; Ferrari, S.M.; Fallahi, P.; Berti, P.; Materazzi, G.; Marchetti, I.; Ugolini, C.; Basolo, F.; Miccoli, P.; Ferrannini, E. Evaluation of the sensitivity to chemotherapeutics or 
thiazolidinediones of primary anaplastic thyroid cancer cells obtained by fine-needle aspiration. Eur. J Endocrinol., 2008, 159, 283-291.

[29] Antonelli, A.; Ferrari, S.M.; Fallahi, P.; Berti, P.; Materazzi, G.; Barani, L.; Marchetti, I.; Ferrannini, E.; Miccoli, P. Primary cell cultures from anaplastic thyroid cancer obtained by fine-needle aspiration used for chemosensitivity tests. Clin. Endocrinol. (Oxf)., 2008, 69, $148-152$.

[30] Antonelli, A.; Ferrari, S.M.; Fallahi, P.; Piaggi, S.; Di Domenicantonio, A.; Galleri, D.; Santarpia, L.; Basolo, F.; Ferrannini, E.; Miccoli, P. Variable modulation by cytokines and thiazolidinediones of the prototype Th1 chemokine CXCL10 in anaplastic thyroid cancer. Cytokine, 2012, 59(2), 218-222.

[31] Smallridge, R.C.; Copland, J.A.; Brose, M.S.; Wadsworth, J.T.; Houvras, Y.; Menefee, M.E.; Bible, K.C.; Shah, M.H.; Gramza, A.W.; Klopper, J.P.; Marlow, L.A.; Heckman, M.G.; Von Roemeling, R. Efatutazone, an oral PPAR- $\gamma$ agonist, in combination with paclitaxel in anaplastic thyroid cancer: results of a multicenter phase 1 trial. J. Clin. Endocrinol. Metab., 2013, 98, 2392-2400.

[32] Conti, I.; Rollins, B.J. CCL2 (monocyte chemoattractant protein-1) and cancer. Semin. Cancer Biol., 2004, 14, 149-154.

[33] Caillou, B.; Talbot, M.; Weyemi, U.; Pioche-Durieu, C.; Al Ghuzlan, A.; Bidart, J.M.; Chouaib, S.; Schlumberger, M.; Dupuy, C. Tumor-associated macrophages (TAMs) form an interconnected cellular supportive network in anaplastic thyroid carcinoma. PLoS One, 2011, 6: e22567.

[34] Richards, D.M.; Hettinger, J.; Feuerer, M. Monocytes and macrophages in cancer: development and functions. Cancer Microenviron, 2013, 6: 179-191.

[35] Schneider, W.M.; Chevillotte, M.D.; Rice, C.M. Interferonstimulated genes: a complex web of host defenses. Annu Rev Immunol, 2014, 32, 513-545.

[36] Antonelli, A.; Rotondi, M.; Ferrari, S.M.; Fallahi, P.; Romagnani, P.; Franceschini, S.S.; Serio, M.; Ferrannini, E. Interferon-gamma-inducible alpha-chemokine CXCL10 involvement in Graves' ophthalmopathy: modulation by peroxisome proliferator-activated receptor-gamma agonists. J. Clin. Endocrinol. Metab., 2006, 91, 614-620. 
[37] Antonelli, A.; Fallahi, P.; Ferrari, S.M.; Carpi, A.; Berti, P.; Materazzi, G.; Minuto, M.; Guastalli, M.; Miccoli, P. Dedifferentiated thyroid cancer: a therapeutic challenge. Biomed. Pharmacother., 2008, 62, 559-563.

[38] Salvatore, G.; Giannini, R.; Faviana, P.; Caleo, A.; Migliaccio, I.; Fagin, J.A.; Nikiforov, Y.E.; Troncone, G.; Palombini, L.; Basolo, F.; Santoro, M. Analysis of BRAF point mutation and RET/PTC rearrangement refines the fine-needle aspiration diagnosis of papillary thyroid carcinoma. J. Clin. Endocrinol. Metab., 2004, 89, 5175-5180.

[39] Antonelli, A.; Bocci, G.; Fallahi, P.; La Motta, C.; Ferrari, S.M.; Mancusi, C.; Fioravanti, A.: Di Desidero, T.; Sartini, S.; Corti, A.; Piaggi, S.; Materazzi, G.; Spinelli, C.; Fontanini, G.; Danesi, R.; Da Settimo, F.; Miccoli, P. CLM3, a multitarget tyrosine kinase inhibitor with antiangiogenic properties, is active against primary anaplastic thyroid cancer in vitro and in vivo. J. Clin. Endocrinol. Metab., 2014, 99, E572-E581.

[40] Fallahi, P,; Ferrari, S.M.; La Motta, C.; Materazzi, G.; Bocci, G.; Da Settimo, F.; Miccoli, P.; Antonelli, A. CLM29 and CLM24, pyrazolopyrimidine derivatives, have antitumoral activity in vitro in anaplastic thyroid cancer, with or without BRAF mutation. Endocrine, 2016, 53(1), 136-44.

[41] Antonelli, A.; Ferrari, S.M.; Fallahi, P.; Frascerra, S.; Piaggi, S.; Gelmini, S.; Lupi, C.; Minuto, M.; Berti, P.; Benvenga, S.; Basolo, F.; Orlando, C.; Miccoli, P. Dysregulation of secretion of CXC alpha-chemokine CXCL10 in papillary thyroid cancer: modulation by peroxisome proliferator-activated receptor-gamma agonists. Endocr. Relat. Cancer., 2009, $16,1299-1311$.

[42] Antonelli, A.; Bocci, G.; La Motta, C.; Ferrari, S.M.; Fallahi, P.; Fioravanti, A.; Sartini, S.; Minuto, M.; Piaggi, S.; Corti, A.; Alì, G.; Berti, P.; Fontanini, G.; Danesi, R.; Da Settimo, F.; Miccoli, P. Novel pyrazolopyrimidine derivatives as tyrosine kinase inhibitors with antitumoral activity in vitro and in vivo in papillary dedifferentiated thyroid cancer. J. Clin. Endocrinol. Metab., 2011, 96, E288-E296.

[43] Antonelli, A.; Bocci, G.; La Motta, C.; Ferrari, S.M.; Fallahi, P.; Ruffilli, I.; Di Domenicantonio, A.; Fioravanti, A.; Sartini, S.; Minuto, M.; Piaggi, S.; Corti, A.; Alì, G.; Di Desidero, T.; Berti, P.; Fontanini, G.; Danesi, R.; Da Settimo, F.; Miccoli, P. CLM94, a 
novel cyclic amide with anti-VEGFR-2 and antiangiogenic properties, is active against primary anaplastic thyroid cancer in vitro and in vivo. J. Clin. Endocrinol. Metab., 2012, 97, E528-E536.

[44] Antonelli, A.; Fallahi, P.; Nesti, C.; Pupilli, C.; Marchetti, P.; Takasawa, S.; Okamoto, H.; Ferrannini, E. Anti-CD38 autoimmunity in patients with chronic autoimmune thyroiditis or Graves' disease. Clin. Exp. Immunol., 2001, 126, 426-431.

[45] Kasai, K.; Banba, N.; Motohashi, S.; Hattori, Y.; Manaka, K.; Shimoda, S.I. Expression of monocyte chemoattractant protein-1 mRNA and protein in cultured human thyrocytes. FEBS Lett., 1996, 394, 137-140.

[46] Antonelli, A.; Ferrari, S.M.; Frascerra, S.; Corrado, A.; Pupilli, C.; Bernini, G.; Benvenga, S.; Ferrannini, E.; Fallahi, P. Peroxisome proliferator-activated receptor $\alpha$ agonists modulate Th1 and Th2 chemokine secretion in normal thyrocytes and Graves' disease. Exp. Cell Res., 2011, 317, 1527-1533.

[47] Antonelli, A.; Ferrari, S.M.; Frascerra, S.; Ruffilli, I.; Pupilli, C.; Bernini, G.; SellariFranceschini, S.; Gelmini, S.; Ferrannini, E.; Fallahi, P. $\beta$ (CCL2) and $\alpha$ (CXCL10) chemokine modulations by cytokines and peroxisome proliferator-activated receptor- $\alpha$ agonists in Graves' ophthalmopathy. J. Endocrinol. 2012, 213, 183-191.

[48] Goulvestre, C.; Batteux, F.; Charreire, J. Chemokines modulate experimental autoimmune thyroiditis through attraction of autoreactive or regulatory T cells. Eur. J. Immunol., 2002, $32,3435-3442$.

[49] Shimada, M.; Andoh, A.; Araki, Y.; Fujiyama, Y.; Bamba, T. Ligation of the Fas antigen stimulates chemokine secretion in pancreatic cancer cell line PANC-1. J. Gastroenterol. Hepatol., 2001, 16, 1060-1067.

[50] Yamana, J.; Santos, L.; Morand, E. Enhanced induction of LPS-induced fibroblast MCP-1 by interferon-gamma: involvement of JNK and MAPK phosphatase-1. Cell. Immunol., 2009, 255, 26-32.

[51] Denk, A.; Goebeler, M.; Schmid, S.; Berberich, I.; Ritz, O.; Lindemann, D.; Ludwig, S.; Wirth, T. Activation of NF-kappa B via the Ikappa B kinase complex is both essential and 
sufficient for proinflammatory gene expression in primary endothelial cells. J. Biol. Chem., 2001, 276, 28451-28458.

[52] Takahashi, M.; Suzuki, E.; Takeda, R.; Oba, S.; Nishimatsu, H.; Kimura, K.; Nagano, T.; Nagai, R.; Hirata, Y. Angiotensin II and tumor necrosis factor-alpha synergistically promote monocyte chemoattractant protein-1 expression: roles of NF-kappaB, p38, and reactive oxygen species. Am. J. Physiol. Heart Circ. Physiol., 2008, 294, H2879-H2888.

[53] Funakoshi-Tago, M.; Shimizu, T.; Tago, K.; Nakamura, M.; Itoh, H.; Sonoda, Y.; Kasahara, T. Celecoxib potently inhibits TNFalpha-induced nuclear translocation and activation of NF-kappaB. Biochem. Pharmacol., 2008, 76, 662-671.

[54]Ho, A.W.; Wong, C.K.; Lam, C.W. Tumor necrosis factor-alpha up-regulates the expression of CCL2 and adhesion molecules of human proximal tubular epithelial cells through MAPK signaling pathways. Immunobiology, 2008, 213(7), 533-544.

[55] Lee, J.H.; Woo, J.H.; Woo, S.U.; Kim, K.S.; Park, S.M.; Joe, E.H.; Jou, I. The 15-deoxydelta 12,14-prostaglandin J2 suppresses monocyte chemoattractant protein-1 expression in IFN-gamma-stimulated astrocytes through induction of MAPK phosphatase-1. $J$. Immunol., 2008, 181, 8642-8649.

[56] Dasu, M.R.; Park, S.; Devaraj, S.; Jialal, I. Pioglitazone inhibits Toll-like receptor expression and activity in human monocytes and db/db mice. Endocrinology, 2009, 150(8), 3457-3464.

[57] Marx, N.; Mach, F.; Sauty, A.; Leung, J.H.; Sarafi, M.N.; Ransohoff, R.M.; Libby, P.; Plutzky, J.; Luster, A.D. Peroxisome proliferator-activated receptor-gamma activators inhibit IFN-gamma-induced expression of the T cell-active CXC chemokines IP-10, Mig, and I-TAC in human endothelial cells. J. Immunol., 2000, 164, 6503-6508.

[58] Lombardi, A.; Cantini, G.; Piscitelli, E.; Gelmini, S.; Francalanci, M.; Mello, T.; Ceni, E.; Varano, G.; Forti, G.; Rotondi, M.; Galli, A.; Serio, M.; Luconi, M. A new mechanism involving ERK contributes to rosiglitazone inhibition of tumor necrosis factor-alpha and interferon-gamma inflammatory effects in human endothelial cells. Arterioscler. Thromb. Vasc. Biol., 2008, 28, 718-724. 
[59] Grommes, C.; Landreth, G.E.; Heneka, M.T. Antineoplastic effects of peroxisome proliferator-activated receptor gamma agonists. Lancet Oncol., 2004, 5, 419-429.

[60] Copland, J.A.; Marlow, L.A.; Kurakata, S.; Fujiwara, K.; Wong, A.K.; Kreinest, P.A.; Williams, S.F.; Haugen, B.R.; Klopper, J.P.; Smallridge, R.C. Novel high-affinity PPARgamma agonist alone and in combination with paclitaxel inhibits human anaplastic thyroid carcinoma tumor growth via p21WAF1/CIP1. Oncogene, 2006, 25(16), 2304-2317. 


\section{Figure Legends}

Figure 1 The effect of TNF-a, IFN-g, or of IFN-g+TNF-a, of rosiglitazone (Rosi; 20 mmol L-1; with IFNg+TNF-a), and of pioglitazone (Pio; $20 \mathrm{mmol} \mathrm{L}^{-1}$; with IFN-g+TNF-a) on CCL2 secretion is shown in 8 different ATC cell preparations. Bars are mean \pm SEM. $*=P<0.05$ or less versus control (Ctrl) by Bonferroni-Dunn test; $* *=P<0.05$ or less versus IFN; $*^{*}=P<0.05$ or less versus IFN+TNF.

Figure 2 The effect of TNF-a, IFN-g, or of IFN-g+TNF-a, of rosiglitazone (Rosi; 20 mmol L-1; with IFN$\mathrm{g}+\mathrm{TNF}-\mathrm{a}$ ), and of pioglitazone (Pio; $20 \mathrm{mmol} \mathrm{L}^{-1}$; with IFN-g+TNF-a) on CCL2 secretion is shown in 5 different TFC preparations. The results are the mean of the 5 samples. Bars are mean \pm SEM. $*=P<$ 0.05 or less versus control (Ctrl) by Bonferroni-Dunn test; $* *=P<0.05$ or less versus IFN.

Figure 3 (A) The results of WST-1 assay in ANA (after $48 \mathrm{~h}$ of incubation with pioglitazone - Pio) showed a reduction of proliferation with respect to the control both at $1 \mathrm{~h}$ (from the start of tetrazolium reaction) [of $8 \%$ and $17 \%$ with pioglitazone $10(P=\mathrm{ns})$ or $20(P<0.01) \mathrm{mmol} \mathrm{L}^{-1}$, and at $2 \mathrm{~h}(\mathbf{B})$ [of $10 \%$ and $24 \%$ with pioglitazone $10(P<0.05)$ or $\left.20(P<0.0001) \mathrm{mmol} \mathrm{L}^{-1}\right](P$ by ANOVA $)$. (C) The percentage of apoptotic cells increased dose-dependently treating them with pioglitazone (Pio) 10 or 20 mmol L ${ }^{-1}$ (ANOVA, $P<0.001$ ). Bars are mean \pm SEM. * $=P<0.05$ or less versus Control by Bonferroni-Dunn test.

Figure 4 (A) NF-kB was constitutively activated in ATC cells (CTRL; lane 3) and its DNA binding activity increased with IFN-g and TNF-a (IFN+TNF; lane 4). Pioglitazone (PIO; 20 mmol L-1) alone (lane 2) or combined with IFN-g and TNF-a (IFN+TNF+PIO; lane 1) significantly reduced the IFN-g and TNFa activation of NF-kB. (B) ERK1/2 are basally activated in ATC cells (Cont), IFN-g+TNF-a (TNF-INT) stimulated its activation. Pioglitazone (PIO; $20 \mathrm{mmol} \mathrm{L}^{-1}$ ) inhibited the cytokines-induced ERK1/2 phosphorilation. 

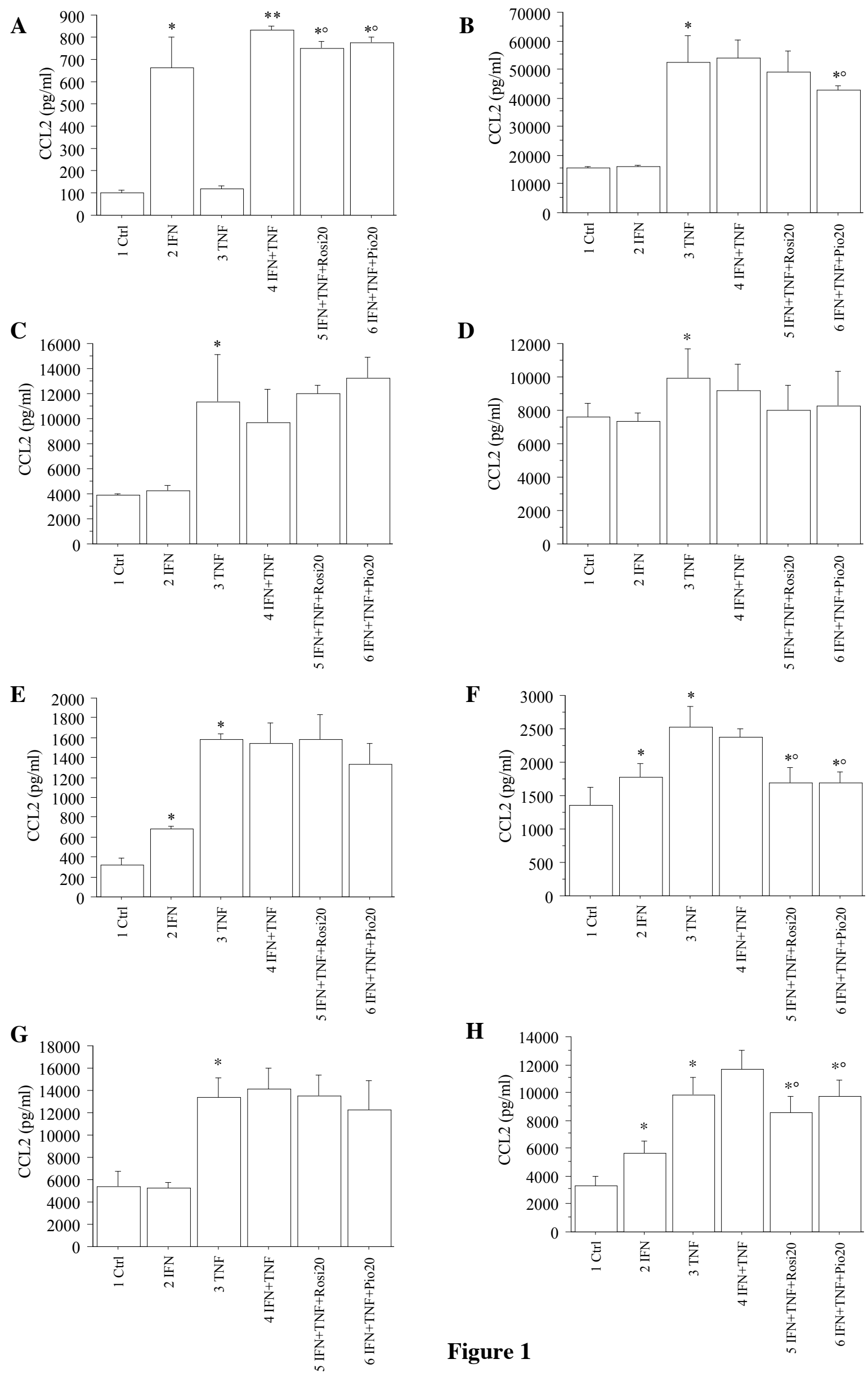

H

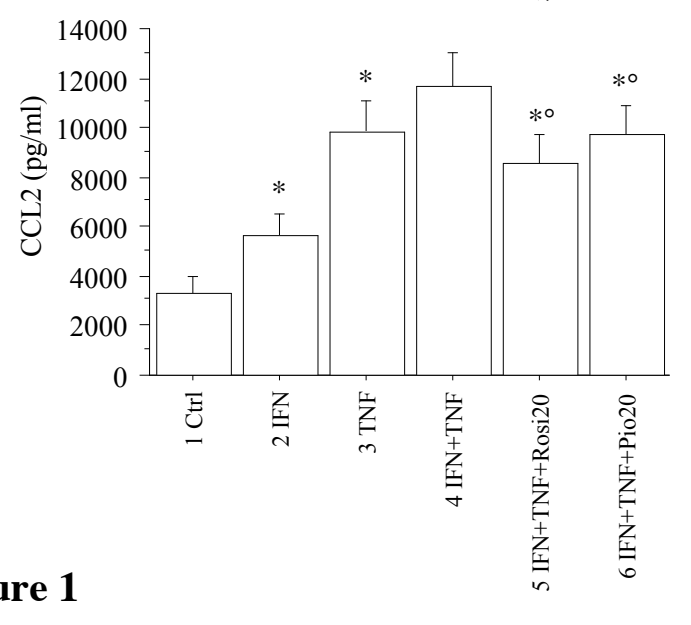




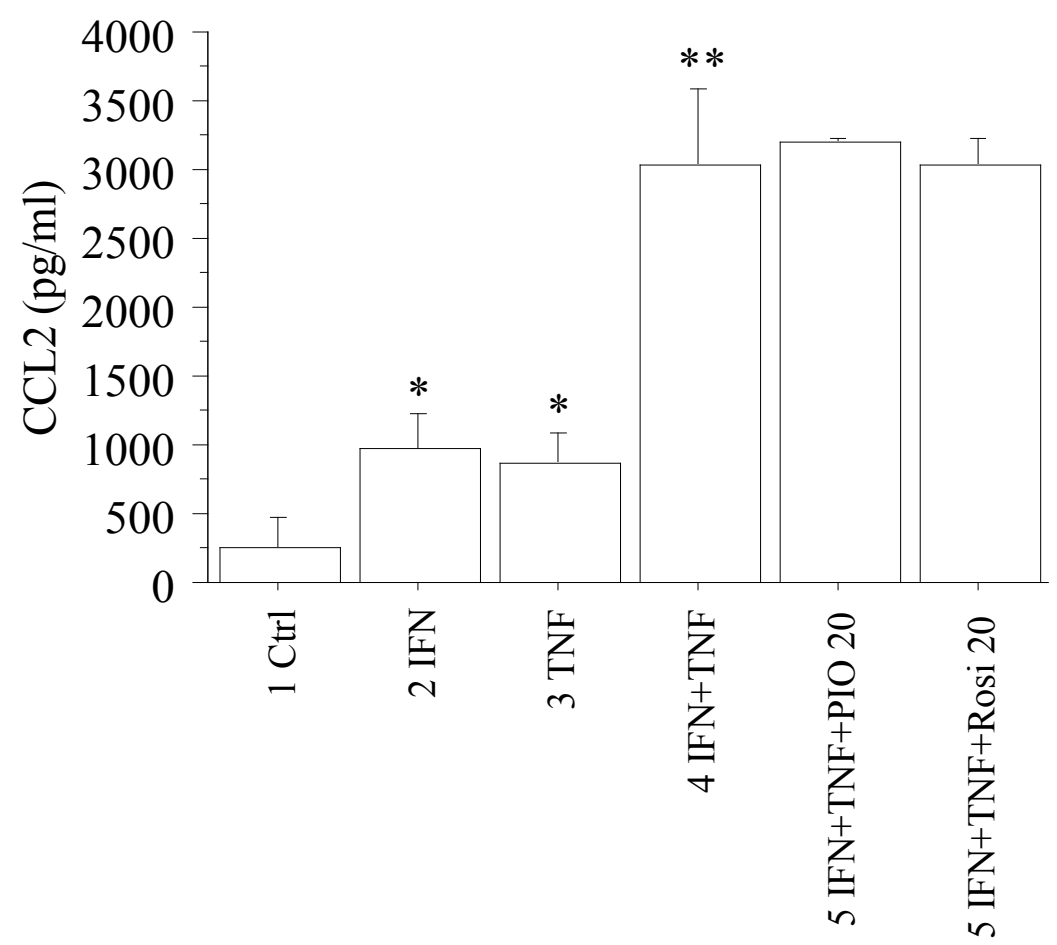

Figure 2 
A

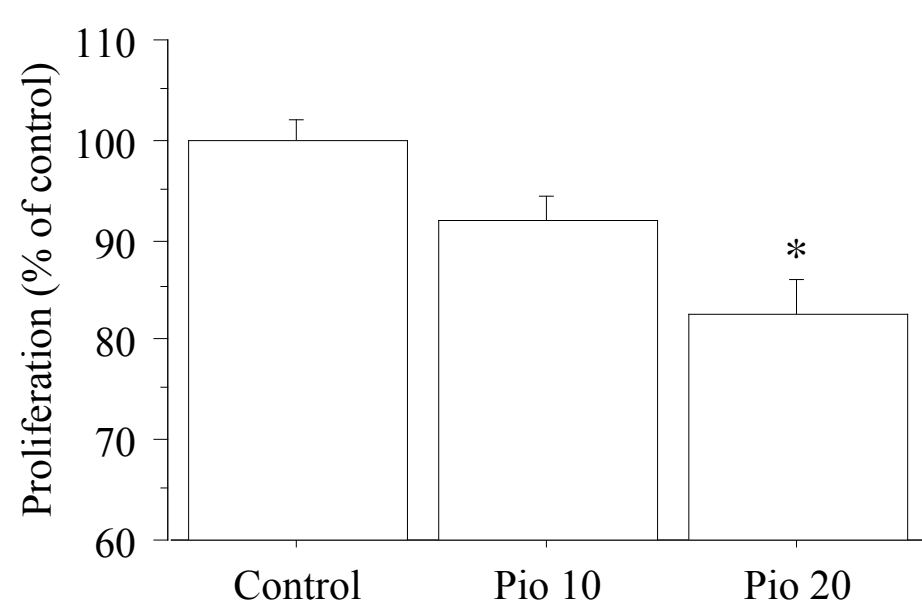

B

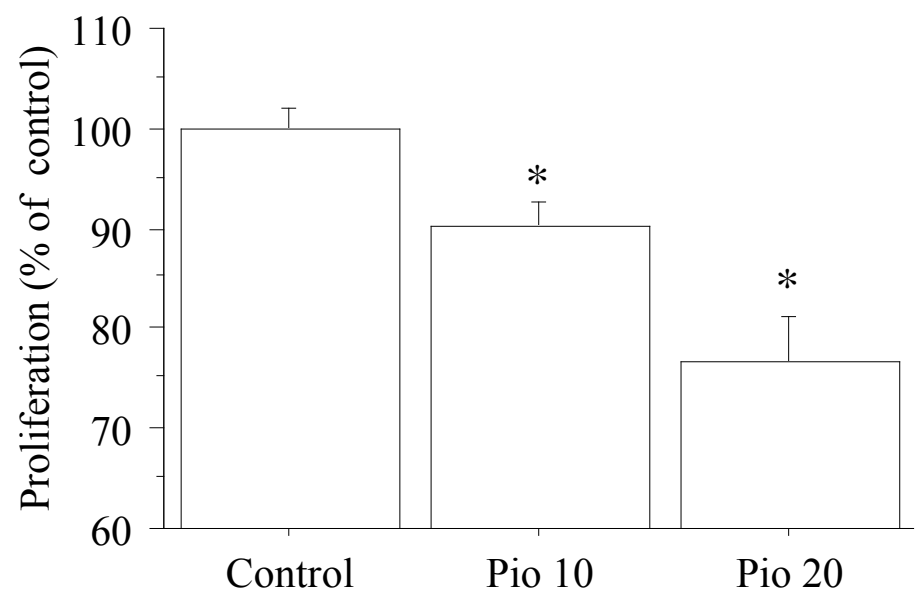

C

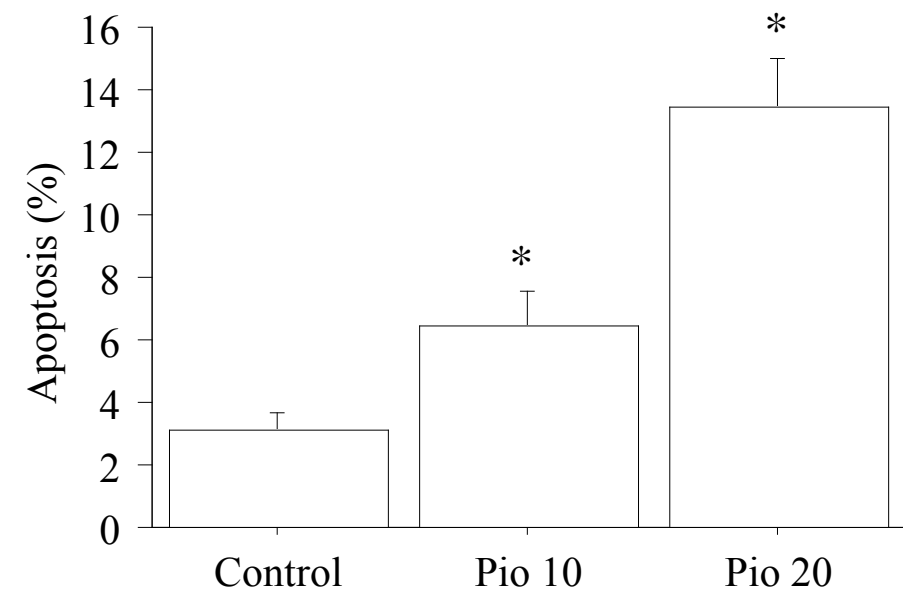

Figure 3 
A

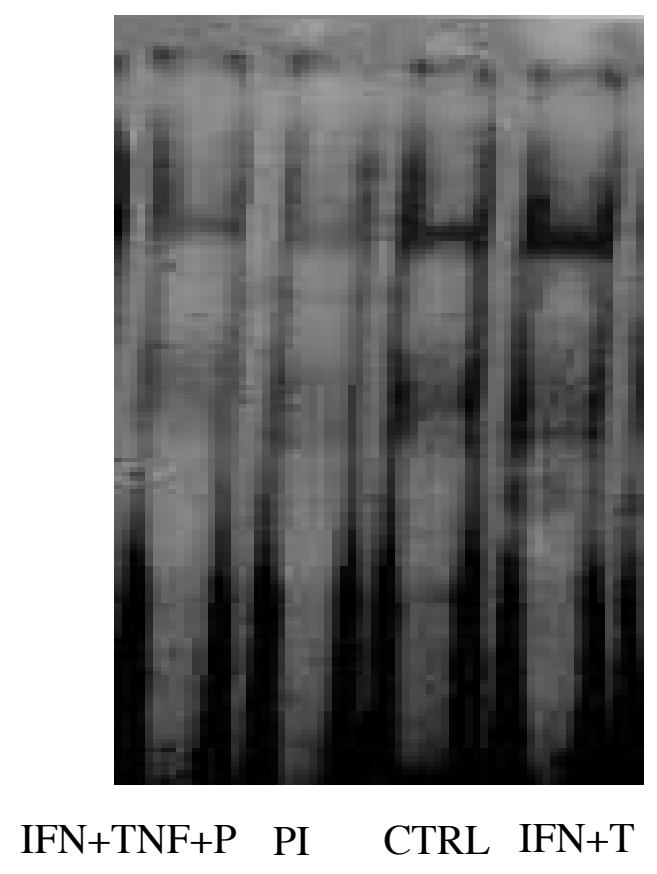

B

\section{P-ERK1/2}

\section{ERK1/2}

Actine

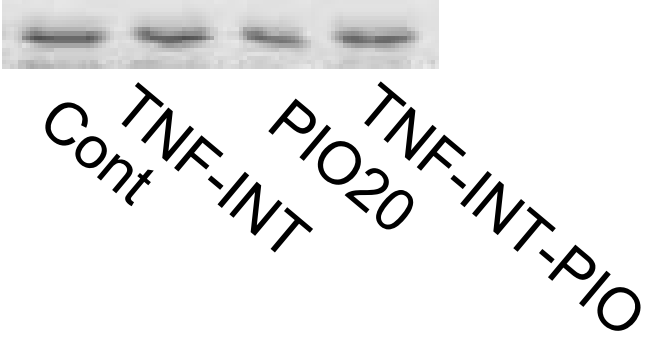

Figure 4 